\title{
Remote Sensing and GIS Tool to Detect Hydrocarbon Prospect in Nagapattinam Sub Basin, India
}

\author{
S. Prabaharan • M. Ramalingam • \\ T. Subramani $\cdot$ C. Lakshumanan
}

Received: 23 June 2011/Accepted: 30 October 2012/Published online: 10 November 2012

(C) The Author(s) 2012. This article is published with open access at Springerlink.com

\begin{abstract}
Cauvery Basin is one of the pericratonic rift basins located in the east coast of Tamilnadu. The rifting has resulted in a series of horsts and grabens. The present study uses a new technique which was devised with the help of GIS by analyzing the surface lineaments and subsurface linearities effectively. In this present study, a satellite image based analysis was conducted for extracting surface lineaments, and for the subsurface linearities, the basement linearities were extracted from seismic, magnetic, and gravity data. An orientation analysis of these surface and subsurface linear features was performed to detect the basic structural grains of the study area. The correlation between these structural grains and subsurface oil and gas traps was performed to understand the connectivity to the reservoirs. This article discusses in detail about the same and the importance of using surface and subsurface lineament analyses for
\end{abstract}

S. Prabaharan $(\bowtie) \cdot$ T. Subramani

Department of Geology, Anna University,

Chennai 600 025, India

e-mail: haripraba@gmail.com

\section{Ramalingam}

Institute of Remote Sensing, Anna University,

Chennai 600 025, India

C. Lakshumanan

Centre for Remote Sensing, Bharathidasan University,

Trichirapalli 600 023, India delineating hydrocarbon reservoirs in the Nagapattinam Sub-Basin of Cauvery Basin.

Keywords Lineaments - Structural grains · IRS P-6 · LISS III · Cauvery Basin

\section{Introduction}

Cauvery Basin, formed during late Jurassic period by sagging of a part of the Indian shield mainly along the dominant NE-SW eastern ghats trend, is located in the southern part of east coast of India between the northerly plunging Sri Lanka basement massif and the peninsular craton (Subramanyam et al. 1995). It occupies an area of 25,000 sq km on land basin and $35,000 \mathrm{sq} \mathrm{km}$ offshore (Kumar 1983). Subsurface studies over onshore parts of the basin have revealed the basinal trend and the main NE-SW structural features, viz., Pondicherry, Tranquebar, and Nagapattinam depressions, separated by Kumbakonam-Shiyali ridge, Karaikal high and Vedaranyam high (Sastri et al. 1973; Kumar 1983; Venkatarengan 1987). Geomorphological and morphotectonic studies have been carried out by many earlier researchers based on air photos and landsat images (Varadarajan 1969; Varadarajan and Balakrishnan 1982; Mahajan et al. 1984; Mitra and Agarwal 1991). The surface linear features have been used to search for additional reserves in mature oil gas fields (Herman et al. 1986; Guo and Carroll 1995). 


\section{Study Area}

The study area lies between North Latitudes $10^{\circ} 16^{\prime} 41^{\prime \prime}-$ $10^{\circ} 59^{\prime} 14^{\prime \prime}$ and East Longitudes $79^{\circ} 15^{\prime} 26^{\prime \prime}-79^{\circ} 51^{\prime} 56^{\prime \prime}$ covering parts of Survey of India topo maps $58^{\circ} \mathrm{N}-$ 5,6,7,9,10,11,13,14 and 15. Nagapattinam Sub-Basin covers Thiruvarur, Thanjavore, and Nagapattinam. The total study area occupies 5,249 sq $\mathrm{km}$. The study area location map is shown in Fig. 1.

\section{Geological History and General Stratigraphy}

The rifting of Cauvery Basin was initiated during late Jurassic (Blanford 1865). The detailed tectonic map of the Cauvery basin is as shown in Fig. 2. However, the oldest sediments recorded in the subsurface by Oil and Natural Gas Corporation palynologists are Neocomian. The Neocomian sediments are devoid of microfauna and are dated with palynofossils. Therefore, it is evident that Cauvery Basin has not experienced marine transgression until Aptian. Granitic wash sediments derived from granitic provenance are rich in Biotite mica and Potash feldspar, and as a result, these sandstones with thin micaceous and carbonaceous shale intercalations exhibit a serrated high ' $\gamma$ ' in the ' $\gamma$ ' ray log. As these sands are tight, compacted, calcareous cemented with quartz overgrowth, chloritized mica occyping interstices form the Andimadam reservoirs that are of poor quality (Mani 1999).

Fig. 1 Location map

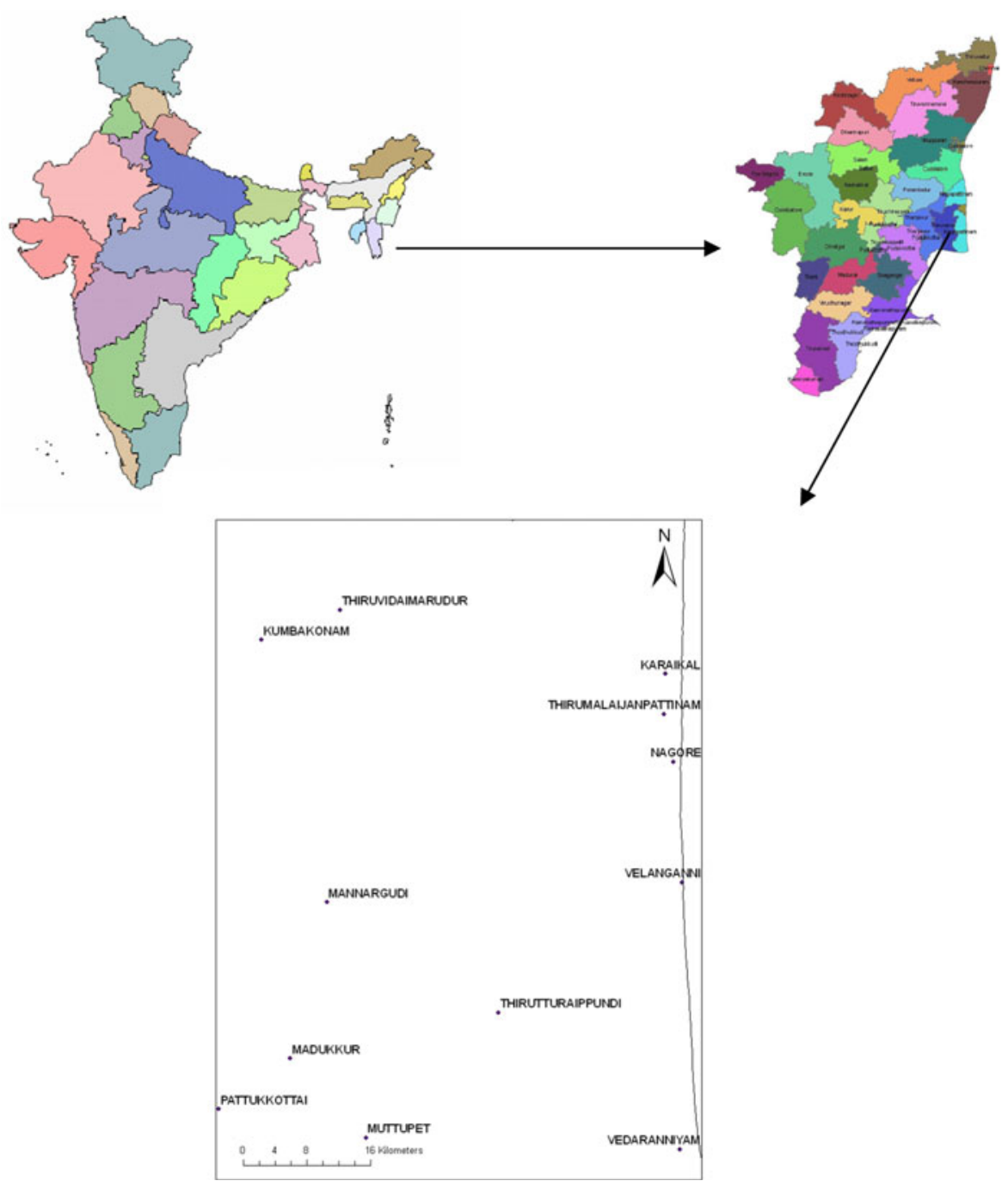


The Cenomanian transgression has resulted in the deposition of finer clastics (Sathapadi Shale) followed by a fall in sea level producing in sandy sediments (Bhuvanagiri Formation) during Turonian, and the top of Turonian is an Unconformity.

Coniacian to Maastrichian is mostly finer clastics shaly with frequent input of sand (Nannilam reservoirs are sandwiched in shale. Again, the top of Maastritchian is an unconformity surface. Late Paleocene, Early Eocene period witnessed a major transgression in the Tri-junction area as witnessed by brown colored shales with abundant planktons such as globigerina and Orbulina (Rajagopalan 1965 Govindan and Chidambaram 2000. During Oligocene, shelf edge delta front sands were cyphoned into the slope, and ultimately, these high-density currents deposited their load and got frozen as sand pods one over the other at repeated intervals. Mio-Pliocene witnessed the development of the present delta with upland area occupied by laterite and lateritic soil. In the subsurface, Mio/ Pliocene is dominated by deltaic sand, minor Kaolinitic clay, and lignite belt from Neyveli-Jayankondam-
Fig. 2 Tectonic map of Cauvery basin

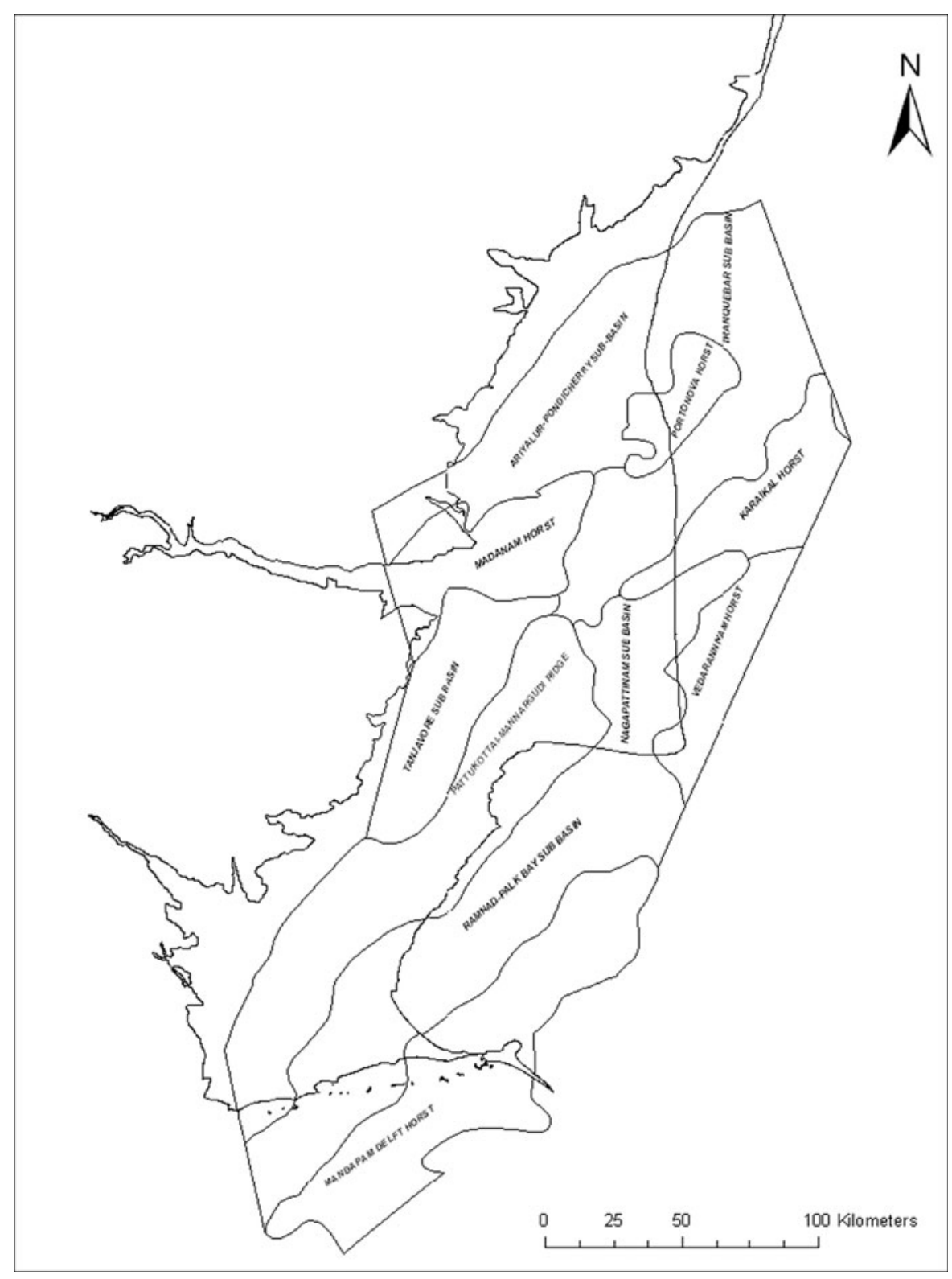


Fig. 3 Geomorphology map

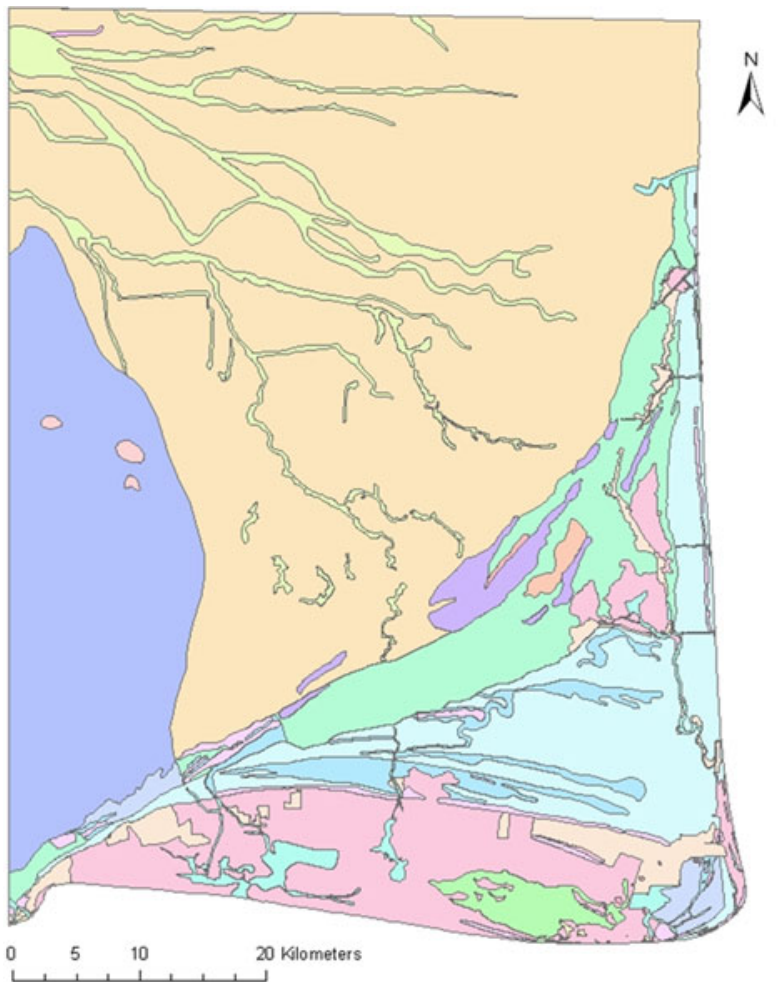

$\stackrel{N}{\Lambda}$

Legend

5 Allurial Plain Canal Command

Beach ridge complex(roung Coastal Plain)

Beach ridge(Young Coastal Plair)

Beach(roung Coastal Plain)

Brachs shwater creeks(roung Coastal Plain)

Buried charnel (Flood Plain)

Coastal Plain Deep

Lagoon(Young Coastal Plain)

Mud flaticoung Coastal Plair

Natural levee (Lower Deltaic Plain)

Older Coastal Plain Deep

Older muchat(Old Coastal Plain)

Paleao Beach ridge(Old Coastal Plain)

Pediplain Canal Command

Reer Islands(roung Coastal Plain)

Sat fat(roung Coastal Plain)

Sand dune

Swale(Old Coastal Plain)

Swale(roung Coastal Plain)

Upland
Mayavaram and end up at Mannargudi which is covered up by the Holocene Delta.

\section{Geomorphology}

The lateritic uplands occur along the western margin of the basin and form the regional erosional plains. The Cauvery River, flowing through the uplands, has migrated anticlockwise from a pivotal point within the uplands, before occupying its present position, as evident from the positions of various paleochannels. The Cauvery delta lacks the protuberance which is regarded as one of the most essential elements of a delta. The recent long shore wave action has made a smooth and straight coastline fringed by beach ridges and swales. A few estuaries and lagoons have developed along the coast indicating submergence. (Mitra and Agarwal 1991) The detailed geomorphic map is shown in Fig. 3.

\section{Methodology}

The surface lineaments are interpreted using the raw and digitally processed IRS LISS III and Landsat satellite

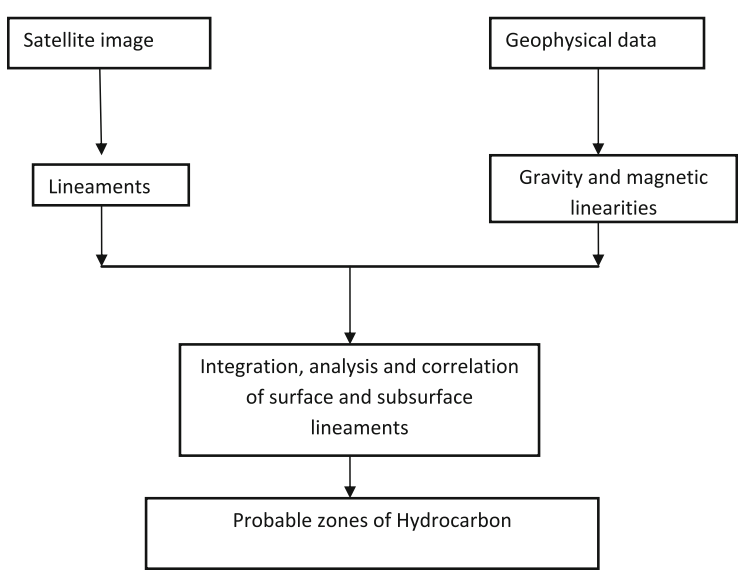

Fig. 4 Methodology

data on 1:50,000 scale. These lineaments/faults are interpreted on the basis of tonal linearities, straightness of river course, soil tonal lineaments, vegetation alignment, etc. The flow chart methodology is shown in Fig. 4.

\subsection{Lineament}

Owing to many capabilities, such as, the synoptic aerial coverage, multi spectral captivity of data, 
Fig. 5 Lineaments interpreted from satellite imagery

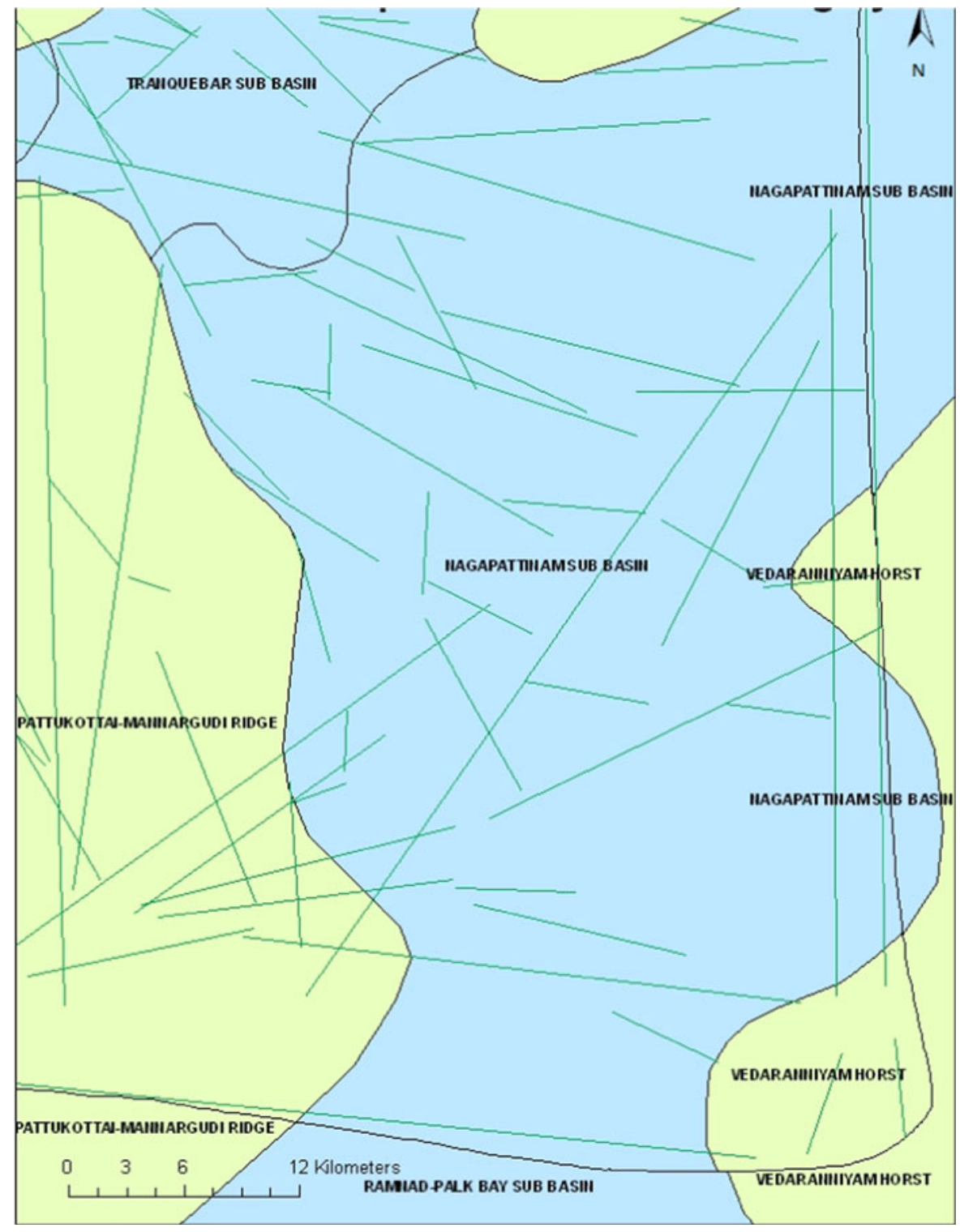

temporal resolution, the satellite images produce better information than conventional aerial photographs (Lillesand and Keifer 1999).Hence, the same has been selected for the task of extracting surface lineaments. The digital image enhancement technique can contribute significantly in extracting the lineaments, the same had been attempted using the software ENVI 4.3. Among different image enhancement techniques, the filtering operations (Suzan and Topark 1998; Chang et al. 1998; Mah et al. 1995), principal component analysis (Qari 1991; Nama 2004), and spectral rationing (Arlegui and Soriano
1998) are the most commonly used ones, and the same have been applied in this study. The final lineament map has been generated by integrating all the lineaments interpreted using raw, FCC, and enhanced satellite data, and GIS layer has been generated as shown in Fig. 5.

\subsection{Subsurface Fault, Gravity, and Magnetic Lineaments}

Avasthi et al. (1977) and Sahu (2007) have analyzed the gravity, the magnetic data, and the basement 
Fig. 6 a Lineament orientation of surface. b Lineament orientation of gravity data. c Lineament orientation of magnetic data
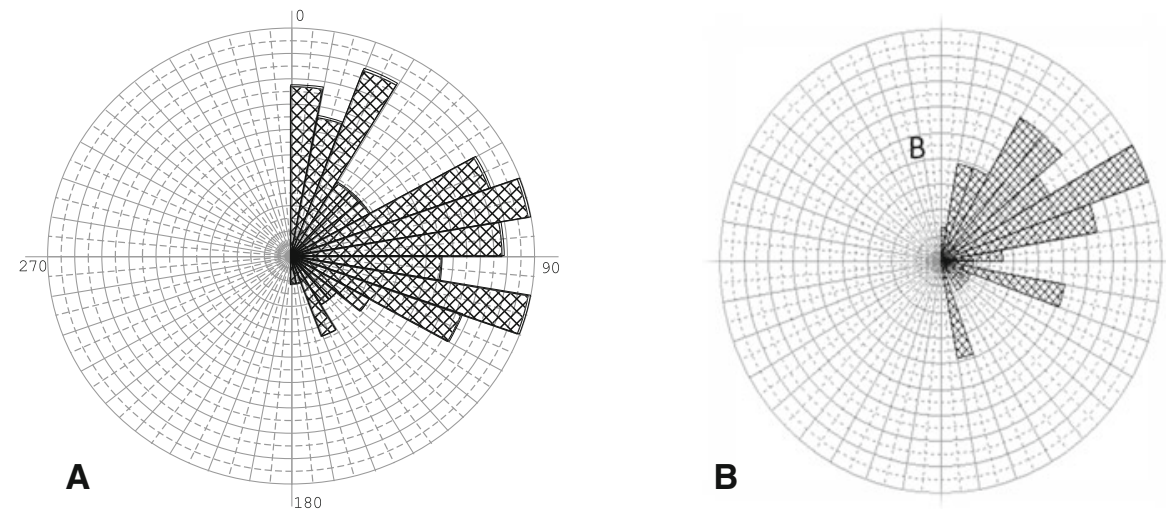

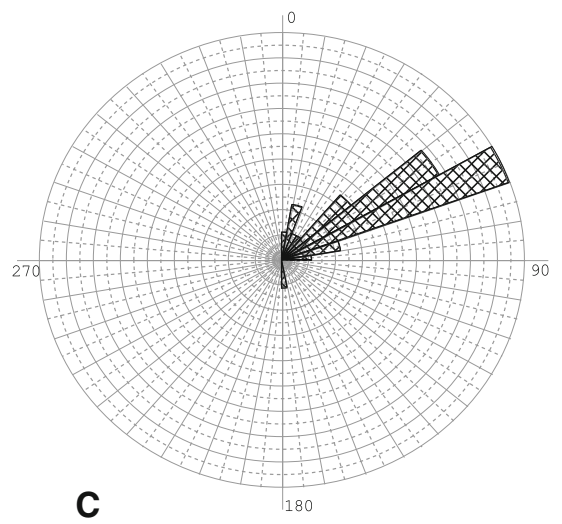

depth. The above published gravity, magnetic, and basement depth maps were georeferenced and rectified using ArcGIS 9.3 and created a database. The gravity and magnetic lineaments have been extracted from visualized breaks of converted 3D maps of both gravity and magnetic contour maps, and the same were digitized and GIS layers have been generated. Another GIS layer on basement faults system was prepared as a result of seismic interpretations of top basement horizon of the area. The basement linearities and other identified linearities were correlated with the surface lineaments interpreted from IRS P-6 LISS III image, SRTM, and Landsat image.

\section{Results and Discussions}

Lineament feature orientation is considered as one of the most important characteristics as far as petroliferous locales are concerned. In the present study, the lineaments, fractures, and their traces seen on the surface lineaments, gravity, magnetic linearities, and basement faults are analyzed for their orientations. Rose diagrams are one form of the most informative ways of representing orientation data. Rose diagrams for all the linear features acquired in the study area are shown in Fig. 6. They are generated based on their trends and frequency. However, one can see from these rose diagrams that the surface linear features in the study area have four preferred orientations: Northwest-Southeast, Northeast-Southwest, NorthSouth, and East-West. Majority of the surface linear features in the area are oriented in two directions, i.e., one along Northwest-Southeast and the other along Northeast-Southwest. However, those surface linear features oriented in the North-South and/or East-West are less prevalent.

The rose diagram of the basement fault system in the area shows that they are preferably oriented in Northwest-Southeast direction. The gravity lineaments appear primarily in four sets: two major sets 
Fig. 7 Lineaments interpreted from gravity data

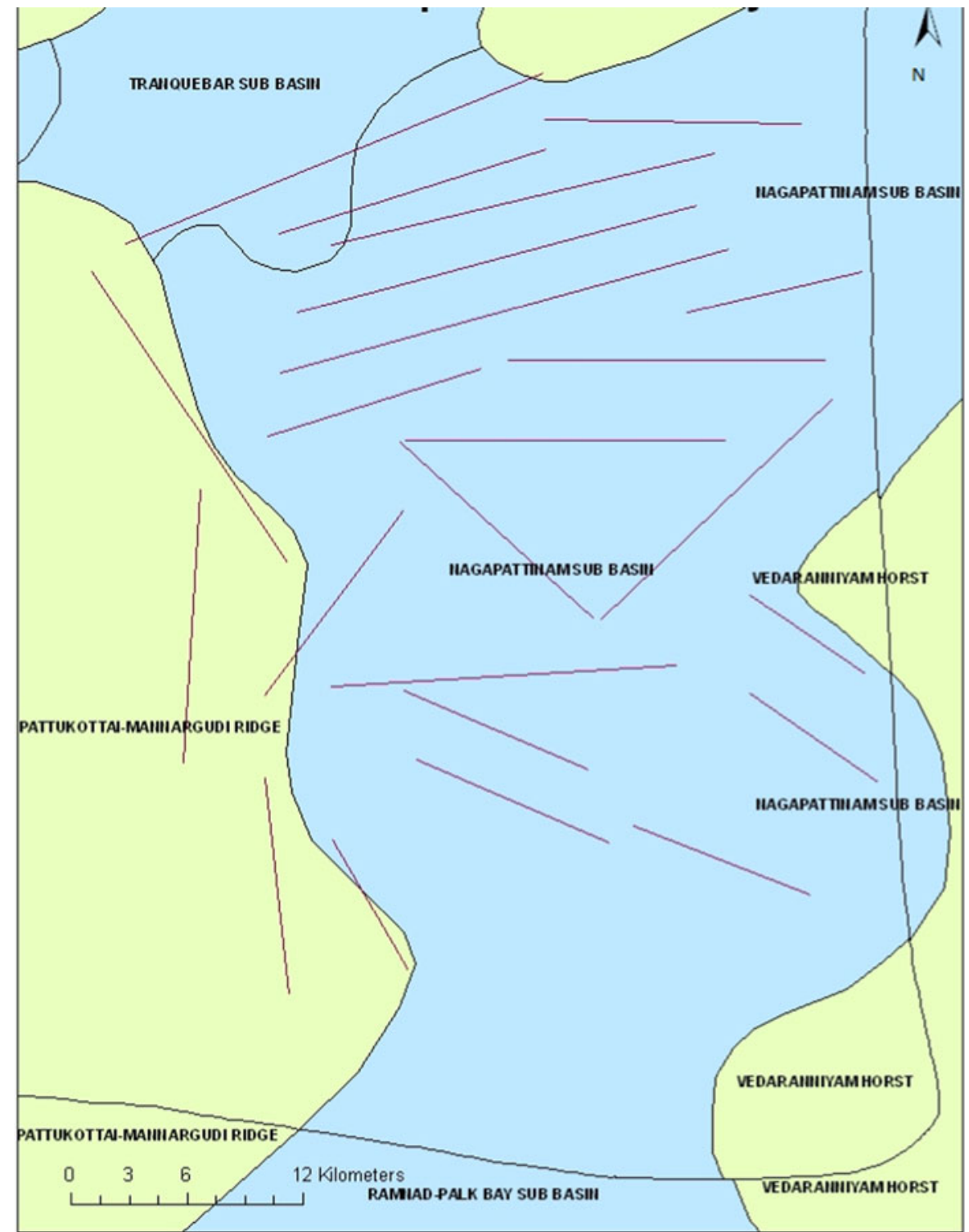

are oriented in Northeast-Southwest and East-West; and the other two minor sets are oriented in Northwest-Southeast and North-South. Fig. 7. Magnetic lineaments appear primarily in three sets: one major set oriented Northeast-Southwest, and two minor sets oriented in Northwest-Southeast and East-West, Fig. 8. A comparison of the surface and subsurface linear features indicates that the basement faults are very much congruent in orientation with the gravity, magnetic and surface lineaments in the region of study. The Precambrian basement fault system consists of a major set trending in the NortheastSouthwest direction, Fig. 9. These faults later were reactivated, and thus they acted as conduits for the upward propagation of hydrocarbon and were entrapped in the shallower/younger rocks, as reflected by the geophysical anomalies and the surface lineaments. During the process of reactivation and propagation, additional sets of faults and fractures were developed because of local structural and tectonic disturbances and their complications. The connectivity from the basement fault systems upward till the 
Fig. 8 Lineaments interpreted from magnetic data

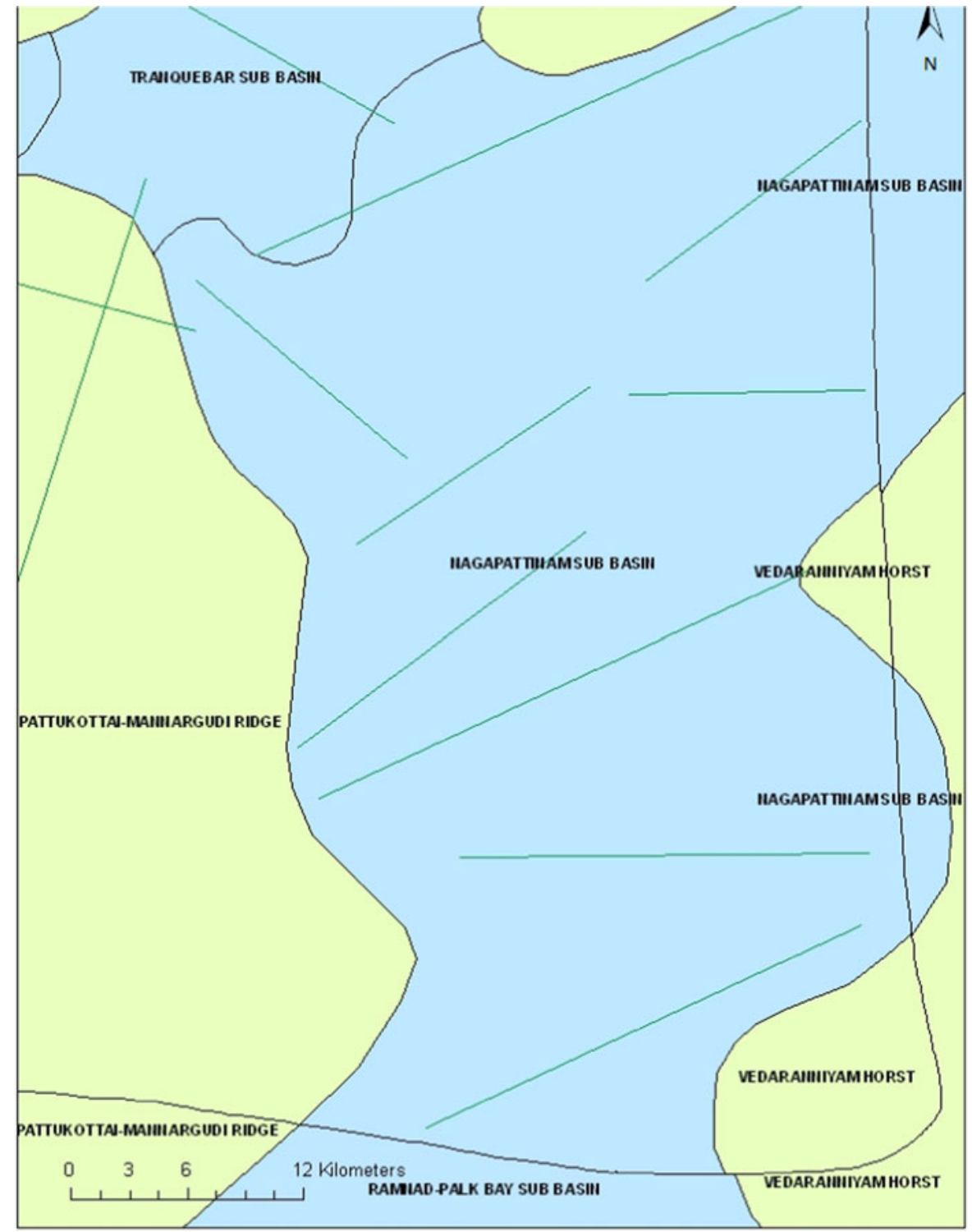

surface provides a mechanism for hydrocarbon migration and entrapment.

In GIS overlay analysis, satellite lineaments have been parallelism with subsurface magnetic linearities, gravity breaks, coincided with existing oil/gas fields. Based on the analysis, new prospective zones were identified and marked Fig. 10. Some of the locations of the oil fields are bounded by major surface linear features from both sides shaping the boundary of sub graben and sub basins in the area. Thus, the surface lineaments can be used as a guide to structural contouring, facies mapping, and delineation of areas of fracture-enhanced permeability. Also, their trends were used directly to conduct seismic programs and to select deeper exploration candidates in the area. Remote sensing and GIS can reduce the conventional method, be cost effective, and narrow down the study area while comparing with the geophysical method.

Open Access This article is distributed under the terms of the Creative Commons Attribution License which permits any use, distribution, and reproduction in any medium, provided the original author(s) and the source are credited. 
Fig. 9 Basement fault map

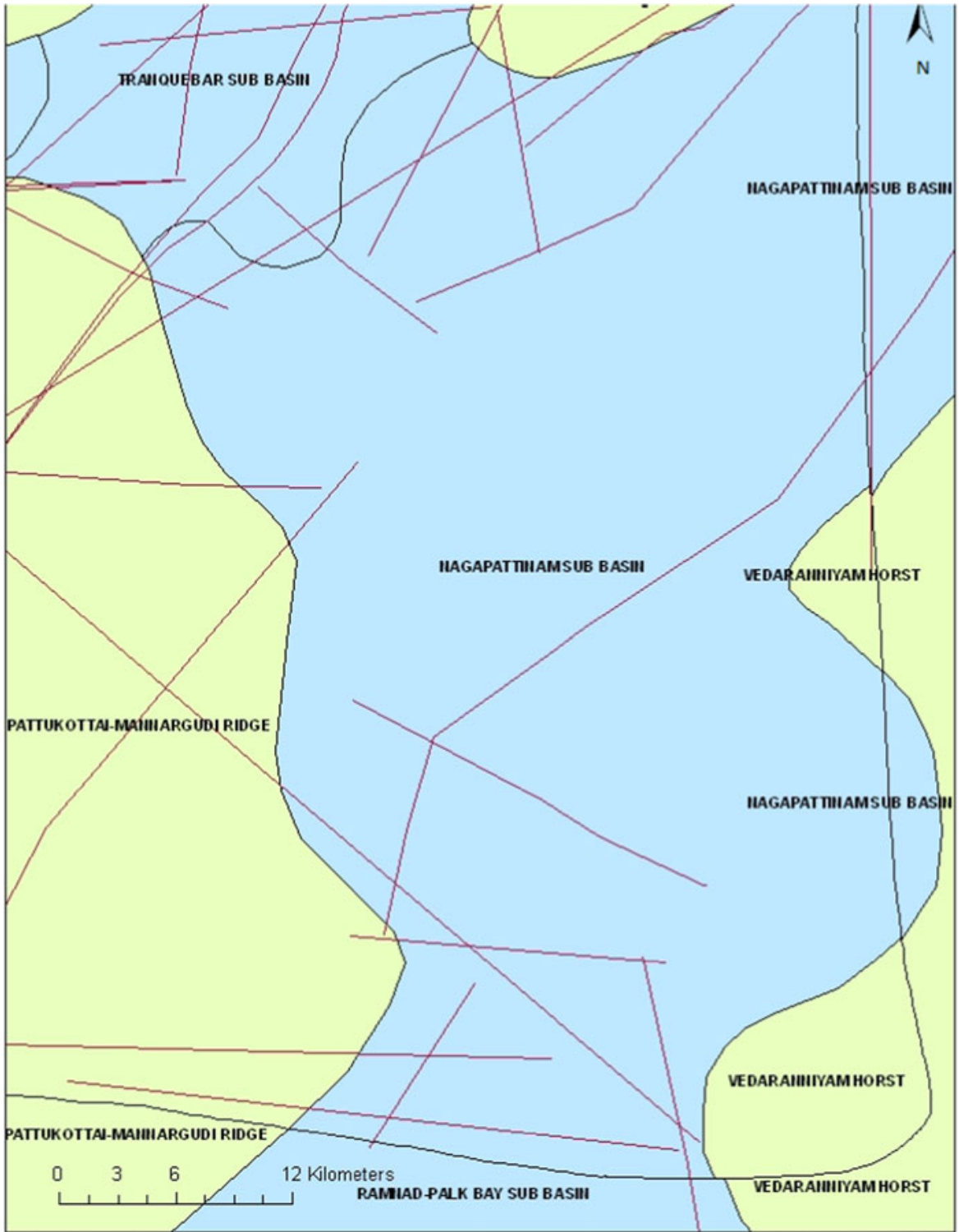


Fig. 10 Lineaments based prospective map

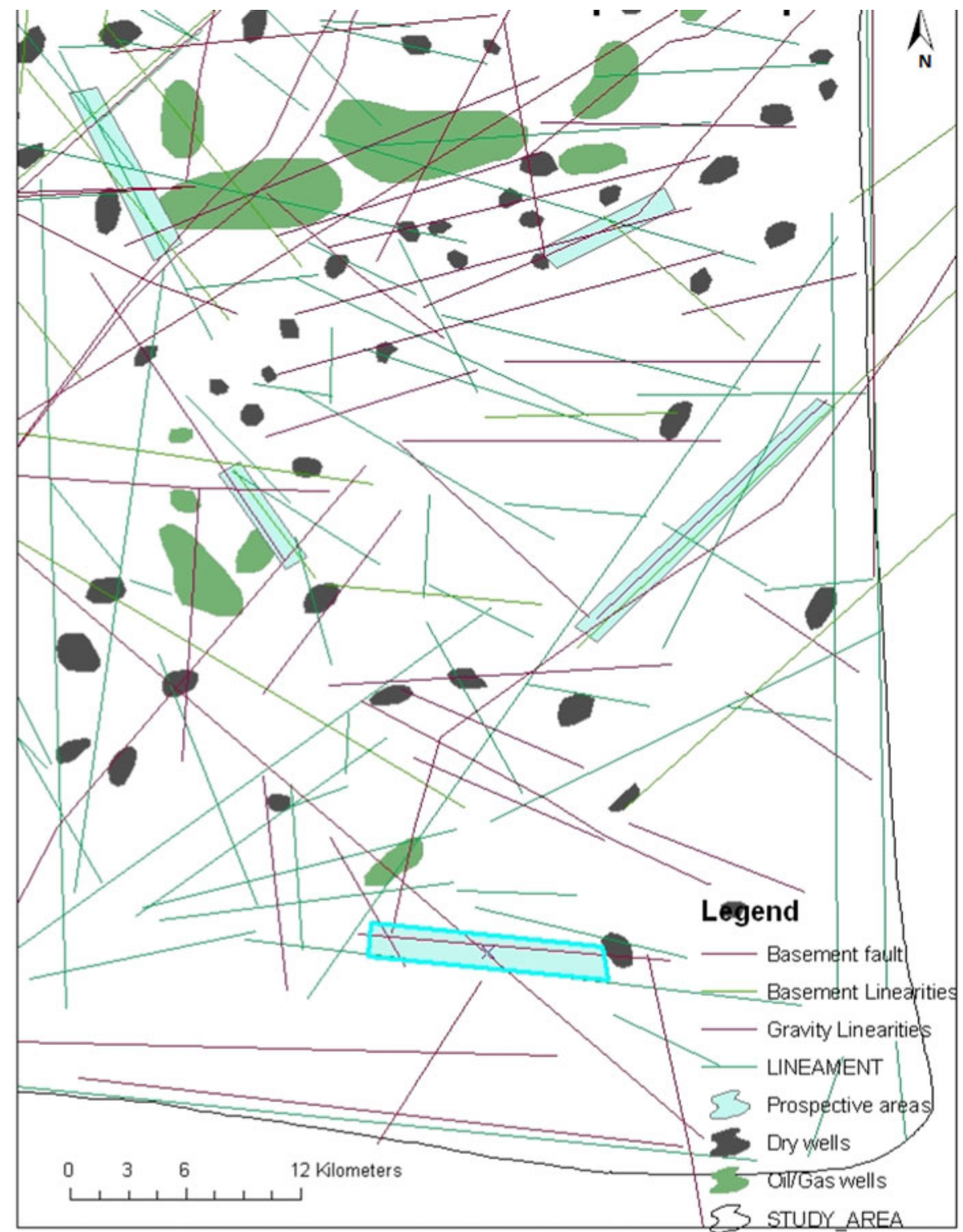

\section{References}

Arlegui LE, Soriano MA (1998) Characterizing lineaments from satellite images and field Studies in the Central Ebro Basin (NE Spain). Int J Remote Sens 19(16):3169-3185

Avasthi DN, Raju VVV, Kashettiyar BY (1977) A case history of geophysical surveys for oil in the Cauvery Basin. Geophys Case Hist India 1:57-77

Blanford HF (1865) Cretaceous and other rocks of the South Arcot and Trichinopoly districts. Memoirs Geol Surv India 4:23-125

Chang Y, Song G, Hsu S (1998) Automatic extraction of ridge valley axes using the profile recognition and polygonbreaking algorithm. Comput Geosci 24(1):83-93
Govindan A, Chidambaram L (2000) Lenticulina Kossmatina a new foraminiferal spectis form the turonian of Cauvery Basin South India. Memoir Geol India 46:205-211

Guo G, Carroll HB (1995) A new methodology for oil and gas exploration using remote sensing data and surface fracture analysis. DOE Report No.NIPER/BDM-0163

Herman J (1986) Remote sensing Study of the Mid-continent Geophysical Anomaly in Iowa. Paper presented at the society of mining engineering fall meeting, St. Louis, Missouri, September 7-10

Kumar SP (1983) Geology and hydrocarbon prospects of Krishna godavari and Cauvery basins. Pet Asia J 57-65

Lillesand TM, Keifer RW (1999) Remote sensing and image interpretation 4 th $(\mathrm{edn})$ 
Mah A et al (1995) Lineament analysis of landsat thematic mapper images, Northern Territory, Australia. Photogramm Eng Remote Sens 61(6):761-773

Mahajan PK, Venkatramaiah S, Shaktawal KS, Ganju JL (1984) Geomorphological evolution of Indian coast with spectial reference to hydrocarbon prospects. ONGC, Unpublished report, $85 \mathrm{p}$

Mani R (1999) Sedimentological modeling of sandstone reservoirs within Andimadam-Bhuvanagiri formations, Cauvery Basin part-I May, unpublished, pp 1-102

Mitra DS, Agarwal RP (1991) Geomorphology and petroleum prospects of Cauvery basin, Tamilnadu, based on interpretation on Indian remote sensing satellite (IRS) data

Nama EE (2004) Lineament detection on mount cameroon during the 1999 Volcanic eruptions using Landsat ETM. Int J Remote Sens 25(3):501-510

Qari MYHT (1991) Application of landsat TM data to geological studies, Al-Khabt Area, Southern Arabian. Photogramm Eng Remote Sens 57(4):421-429

Rajagopalan N (1965) Late cretaceous and early tertiary stratigraphy of Pondicherry, South India. J Geol Soc India 6:108-121
Sahu JN (2007) Hydrocarbon potential and exploration strategy of cauvery basin, India

Sastri VV et al (1973) Stratigraphy and tectonics of sedimentary basins o east coast of peninsular India. AAPG Bull 57:655-678

Subramanyam AS et al (1995) Offshore structural trends from magnetic data over Cauvery basin, east coast of India. J Geol Soc India 46:269-273

Suzan ML, Topark V (1998) Filtering of satellite images in geological lineament analysis: an application to a fault zone in central Turkey. Int J Remote Sens 19(6):1101-1114

Varadarajan K (1969) A report of Photogeomorphological studies carried out in parts of Cauvery basin, ONGC, unpublished report, $12 \mathrm{p}$

Varadarajan K, Balakrishnan MK (1982) structural geomorphology and neotectonics of peninsular India south of $14^{\circ}$ Latitude, ONGC (unpublished report) $30 \mathrm{p}$

Venkatarengan R (1987) Depositional systems and thrust areas for exploration in Cauvery Basin. Bull ONGC 24(1):53-67 